International Journal of Social Science and Economic Research

ISSN: 2455-8834

Volume: 05, Issue: 05 "May 2020"

\title{
DETERMINANT OF RUPIAH EXCHANGE RATE AND MISALIGNMENT (2000-2018)
}

\author{
Sarah Tamery and *Chandra Wijaya \\ Department of Business Administration, Faculty of Administrative Science, \\ Universitas Indonesia, Kampus UI, Depok 16424, Jawa Barat, Indonesia. \\ *Corresponding Author
}

DOI: 10.46609/IJSSER.2020.v05i05.005 URL:https://doi.org/10.46609/IJSSER.2020.v05i05.005 \begin{abstract}
This study aims to analyze the determinants of rupiah exchange rate and explain the amount of currency misalignment. The variables used in this study are real equilibrium exchange rate, terms of trade, net foreign assets, relative price of non-traded to traded goods, trade openness and real interest rate differential. This study uses the Behavioral Equilibrium Exchange Rate (BEER) approach to estimate the rupiah equilibrium value quarterly over the period 2000-2018. The method used in this study is Error Correction Model (ECM). The results of the study found that variables that are significant determinants of long-run equilibrium exchange rates are net foreign assets and terms of trade, while in the short term are terms of traded and relative price of nontraded to traded goods. Based on the estimation of currency misalignment, it was concluded that the rupiah tended to approach equilibrium exchange rates during the study period. In 2001Q2 was the highest undervalued period $-13.51 \%$, while the 2006Q1 period showed the highest overvalued $13 \%$. The findings of this study indicate that the rupiah is still vulnerable to undervaluation shocks.
\end{abstract}

Keywords: Exchange Rate, Equilibrium Exchange Rate, Behavioural Equilibrium Exchange Rate, Misalignment.

\section{INTRODUCTION}

The real exchange rate is a key of relative price. The exchange rate plays an important role in allocating resources and economic transformation, especially in developing countries. (Abhimanyu, 2004). Both real and monetary factors influence the real exchange rate in the short term, and long-term exchange rates are influenced by real factors (Edwards, 1989). For most developing countries, the actual real exchange rate does not always follow the equilibrium 


\section{International Journal of Social Science and Economic Research}

ISSN: $2455-8834$

Volume: 05, Issue: 05 "May 2020"

exchange rate, which is reflected in misalignment, structural or policy-induced and combination of both that will affect macroeconomic performance. If the exchange rate is overvalued, it will affect the lack of external competition and the deterioration of a country's real activity. Conversely, if the exchange rate is undervalued, then the exchange rate will increase exports in the short term and will reduce the current account deficit, but in the long run this will increase inflationary pressures. Previous studies on the topic of exchange rate misalignment have been carried out and are of concern to many academics. Clark and MacDonald (2004) used a behavioral equilibrium exchange rate (BEER) approach that looked at the correlation between the estimated balance between real exchange rates and economic fundamentals. The variables used are the United States, Canada, and England's Real Effective Exchange Rate (REER) with a research period of 1960-1997. The conclusions obtained from this study that the fundamental economic factors that can affect the real exchange rate are interest rate differential, tnt as a proxy the ratio of non-traded prices (domestic Consumer Price Index) to prices of traded goods (Wholesale Price Indices or domestic Producer Price Index), and net foreign assets in United States, Canada, and the United Kingdom, where interest rate differentials are increasing, terms of trade increase and net foreign increases assets will cause the effective real exchange rate to appreciate.

Then research by MacDonald and Dias (2007) objectives to estimate the behavior of the Behavior Equilibrium Exchange Rates (BEERs) of ten industrialized countries and developing countries (Canada, China, Germany, Japan, Norway, Singapore, Sweden, Switzerland, United Kingdom, and the United States). The real exchange rate used is REER. The period of this study was Q1 1988 - Q1 2006. The method used was DOLS estimator panel data. The conclusion of this study, the factors that influence the real exchange rate are the trade balance with a negative correlation; namely the proportion of net exports to GDP, terms of trade with positive correlations, productivity with positive and negative relations, and real interest rates.

Husman's research (2005) aims to determine the factors that influence the nominal exchange rate of the rupiah against the US dollar after the crisis period in 2002-2005 with monthly data using the Error Correction Model (ECM). This study uses a composite model. The variables used in this study are the nominal exchange rate of the rupiah against the US dollar, nominal interest rate differential, a proxy of net foreign assets, namely foreign exchange demand-supply, term of trade, international oil prices and risk indices that afflict political risk, economic risk and financial risk. The results of the study, international oil price variables and risk variables have a negative correlation, foreign exchange demand-supply and terms of trade have a positive correlation. The biggest influence is the risk variable while the variable interest rate differential has very little effect on exchange rate movements. 


\section{International Journal of Social Science and Economic Research}

ISSN: $2455-8834$

Volume: 05, Issue: 05 "May 2020"

Based on the previous research above, the authors are interested in conducting research on the rupiah exchange rate in Indonesia with the BEER method with the dependent variable real equilibrium exchange rate, and the independent variables are variable terms of trade, real interest rate differential, net foreign assets, relative non-traded prices on traded goods, and trade openness. The discussion in this study focuses on the determinants of the equilibrium value of the rupiah and its equilibrium value in the period 2000q1 to 2018q3. In this study, we use quarterly data.

\section{LITERATURE REVIEW}

Basically the definition of rupiah exchange rate can be seen in two aspects, namely the nominal aspect and the real aspect. In the daily context, the exchange rate that we know is the nominal exchange rate, namely the quoted exchange rate. For example IDR / USD which describes how much rupiah is needed to buy 1 US Dollar. With this concept, increasing exchange rates means that the rupiah appreciates for a free floating exchange rate or revaluation system for a fixed exchange rate system, whereas if the exchange rate decreases.

According to Mankiw (2008) the real exchange rate is the relative price of goods between two countries stating the rate at which we can trade goods from a country for goods of another country. The real exchange rate is one of the factors that greatly influences the rise and fall of international trade. Theoretically, if a currency declines, the competitiveness of domestic goods will increase because the price of foreign goods will be more expensive than the price of domestic goods so that import demand will decline and exports will increase so that the trade balance will experience a positive direction.

The equilibrium exchange rate is a value that produces a simultaneous internal and external balance with three conditions, namely the absence of trade barriers, the absence of special incentives for capital inflow and outflow and a reasonable unemployment rate. Equilibrium itself is an exchange rate that reflects the balance in the market for goods and services in a realistic money market and simultaneously increases the effectiveness of monetary control. This means that the rise and fall of an exchange rate is strongly influenced by demand and supply in the foreign exchange market or can be called market fundamentals.

Study entitled "The Real Exchange Rate Misalignment: Application of Behavioral Equilibrium Exchange Rate BEER to Morocco" conducted in 1980 Q1-2012Q4 (Lebadaoui 2013) is an attempt to estimate the behavioral equilibrium exchange rate in Morocco. This study aims to examine the value of equilibrium with the fundamental variables that affect the exchange rate movements of the Moroccan Dirham, whether it experiences under / overvaluation. The variables including the real net capital flows (NKF), terms of trade shocks (TOT), government fiscal 
International Journal of Social Science and Economic Research

ISSN: $2455-8834$

Volume: 05, Issue: 05 "May 2020"

stance (GOV), foreign reserve level (RES), index of monetary policy (MOP) and (PROD) to get it with Cointegration Test and Vector Error Correction Model (VECM). The regression shows that the main fluctuations of the real effective exchange rate are due to trade openness, government spending, terms of trade, the productivity progress, monetary policy and net capital inflow. In the long run all variables are significant, except net capital flow. Whereas in the short run it shows that the dependent variable is influenced by the level of foreign reserve level, terms of trade, trade openness, relative productivity and government spending. Accordingly, and using HP decomposition filter we figure out three periods of under/overvaluation ranging from $2.80 \%$ under to $2.16 \%$ over equilibrium level, furthermore, the misalignment from the equilibrium level needs from five to six years to be eliminated.

The Behavioral Equilibrium Exchange Rate (BEER) approach by Clark and MacDonald (1998) explains the BEER model is one of the derivative models that can capture both the influence of economic and non-economic fundamental factors. The factors that influence the balance of the real long-term exchange rate include factors that influence the trade position between the home country and the world market (terms of trade), tradable and non-tradable sector productivity factors, capital flows and domestic absorption composition (share of investment in GDP). BEER's long-term exchange rate model forms a reduced equation derived from the condition of uncovered interest parity:

$\operatorname{Et}[\Delta \mathbf{S t}+\mathrm{k}]=-(\mathbf{i t}-\mathrm{it} *)+\pi \mathrm{t}$

Equations (1) are converted into real form (minus the difference in inflation expectations: Et ( $\Delta$ Pt- $\Delta \mathrm{Pt}$ ) so that it becomes:

$q \mathrm{t}=\mathrm{Et}[\mathrm{qt}]+\left(\mathbf{r t}-\mathbf{r t}^{*}\right)-\pi \mathrm{t}$

The second equation shows that the current equilibrium exchange rate is determined by three components, namely the expectation of the exchange rate in the period t, the difference in real interest rates with the time period $t$ and risk premium. Risk premium has a negative sign indicating that an increase in risk premium will encourage the depreciation of the real exchange rate. So that equation (2) can be applied, it is assumed that exchange rate expectations, Et $[\Delta \mathrm{qt}+$ $\mathrm{k}]$ are influenced by long-term economic fundamentals, $\mathrm{Zt}$, so that the long-term exchange rate balance becomes:

$q \mathrm{t}=\mathbf{E t}[\Delta \mathrm{qt}]=\mathbf{E}\left[\boldsymbol{\beta}^{\prime} 1 \mathrm{Z1t}\right]=\boldsymbol{\beta}^{\prime} 1 \mathrm{Z1t}$

Factors that can cause systemic variability in q have been widely discussed in previous studies, including Faruqee (1994) and macDonald (1997). These fundamental factors include terms of 


\section{International Journal of Social Science and Economic Research}

ISSN: $2455-8834$

Volume: 05, Issue: 05 "May 2020"

trade (tot), the relative price of traded goods against non-traded goods (the Balassa-Samuelson effect) and net foreign assets (nfa).

$q t=\mathbf{f}($ tott, tntt,nfat $)$

The BEER approach consists in estimating the long-term correlation between the effective real exchange rate observed and a series of fundamentals. Estimates of this long-term correlation are assumed to provide an assessment of the real equilibrium exchange rate. Therefore, deviations from this equilibrium level are in accordance with currency misalignment.

Exchange rate misalignment is the gap between the actual real exchange rate and the real exchange rate of equilibrium (Montiel, 1999). According to Baffes (1999), the misalignment can be divided into two parts, namely descriptive, which is used for a period of time (term) and which is more normative for policy purposes. In the first part, descriptive is done when the market conditions are not perfect where only the response is temporarily ignoring the level of long-term balance. The second part is carried out when observations where the real exchange rate is in a steady state state or in the long run.

The actual condition of the actual exchange rate is not always in its equilibrium value. Generally the actual exchange rate deviation occurs in the short term. This happens because of the inconsistency between economic policies and the prevailing exchange rate system. An example is when the implementation of too expansive monetary policy in the fixed exchange rate system. In addition to the short-term deviation, it turns out that the deviation can be persistent until the deviation is enlarged. This is due to changes in the fundamental variable of the exchange rate not translated into actual changes in the short-term real exchange rate. For example, net foreign assets deteriorate, there will be a depreciation in the equilibrium exchange rate. If the actual real exchange rate does not change to its equilibrium exchange rate there will be misalignment (Kurniati, 1999)

\section{RESEARCH METHODOLOGY}

This research can be categorized as explanatory studies because of testing between hypothesized variables. The data used in this study are included in the time series data with a research data period of 18 years with quarterly data with an observation period of 75 . There is also data used in this study are quantitative data from can be obtained from Bank Economic and Financial Statistics (SEKI) Indonesia, CEIC, The Bank for International Settlements (BIS) in the period 2000 q1 to $2018 q 3$.

The dependent variable in this study is the Real Equilibirium Exchange Rate (REER) which is measured using the International Settlement Bank (BIS) methodology. 
International Journal of Social Science and Economic Research

ISSN: $2455-8834$

Volume: 05, Issue: 05 "May 2020"

The Real Effective Exchange rate (REER) is the weighted normal of a country's currency corresponding to an index or basket of other major currencies. The loads are controlled by contrasting the relative trade balance of a country's currency against each country within the index. REER is utilized to decide an individual country's currency value comparative with the other major currencies in the index and used to assess how a currency is fluctuating against numerous others without a moment's delay, and also used in international trade assessments. Generally, economists and policymakers are more interested in the real effective exchange rate (REER) when measuring a currency's overall alignment. REER, as a proportion of intensity, additionally decides and impacts the presentation of the fare division as a measure of competitiveness, also determines and influences the performance of the export sector (Caballero and Corbo, 1989).

It is because of these allocative and competitive roles of REER that developing and emerging economies are encouraged by IMF to keep the actual REER close to the equilibrium real exchange rate (EREER henceforth), which is defined as the value of the REER consistent with a simultaneous attainment of internal and external equilibrium. Exchange rate misalignment is the sustained departure of actual REER from its EREER is called. In case of misaligned exchange rate, REER fails to perform the allocative role and does not provide the appropriate signals to guide the allocation of resources Montiel (2003) and Edwards (1988)

$R E E R=\sum_{j=1}^{N}$ trade weight $\times$ Real Exchange Rate

Source : Klau dan Fung (2006)

While the independent variables used in this study are terms of trade, net foreign assets, relative price of non-traded to traded goods, real interest rate differrentials, and trade openness.

Terms of trade is the ratio of export prices to the ratio of import prices. The impact of improving the terms of trade on REER is ambiguous a priori (Elbadawi 1994). When terms of trade strengthen, national income (measured by service goods and imports) will increase (income effect). The increase in national income will increase aggregate demand, which will produce an appreciation pressure on the real exchange rate. At the same time strengthening the terms of trade can also reduce foreign demand for domestic exports (substitution effect), which will produce depreciation pressure on the exchange rate (Baffes et. Al 1999). If the income effect dominates the substitution effect, then the strengthening of the terms of trade will appreciate the real exchange rate and vice versa if the substitution effect is the dominant effect

Terms of Trade $=\frac{\text { Export Index Price }}{\text { Import Index Price }}$ 
Source: Abimanyu (2004)

\section{H1: There is a association between TOT and REER}

Net Foreign Assets are calculated from the difference between foreign assets and foreign liabilities, namely the difference between the amount of foreign assets held by domestic residents minus the amount of domestic assets owned by foreign residents. Positive correlation between nfa and the real exchange rate. This is in line with a simple Keynesian framework, that the transmission of changes in the position of net foreign assets to the exchange rate occurs through a trade channel, where the negative nfa position will be covered by surplus trade and surplus trade will result from (relative) depreciating exchange rates.

Net Foreign Assets $=\frac{\text { Net Foreign Assets }}{\text { GDP }}$

Source: Abimanyu (2004)

\section{H2: There is a association between NFA and REER}

Relative Price of Non-Traded to Traded Goods are defined as the ratio of the domestic consumer price index (CPI) to the domestic producer price index - Producer Price Index (PPI). This relates to Macdonald's (1998) equivalent foreign effective (trade weighted) ratio.

Relative Price of Non-Traded to Traded Goods $=\frac{\text { CPI }}{\text { PPI }}$

Source : Lebdaoui (2013)

\section{H3: There is a association between TNT and REER}

The impact of the change in the real international interest rate on the real exchange rate depends on the status of the country concerned as a net debtor nation or net creditor nation. For a country that is a nation's net debtor, an increase in real international interest rates will increase the interest burden, which will then cause depreciation pressure on the real exchange rate. Meanwhile for the net creditor nation, an increase in real international interest rates will actually result in higher interest from abroad, which will create pressure on the real exchange rate (Sahminan, 2005). During the period 2010-2018 Net, Indonesia's international investment position is negative (Bank Indonesia) so that Indonesia is considered a Net Debtor Nation. So that the provisional suspicion that an increase in international interest rates will cause a depreciation of the real exchange rate in Indonesia.

Real Interest Rate Differential $=$ Real Interest Rate Indonesia - Real Interest Rate Amerika Serikat 
Source : Abimanyu (2004)

\section{H4: There is a association between RDIF and REER}

According to the Dornbusch (1974) trade liberalization model and based on certain assumptions regarding the subsitability of non-radeable goods and services, an increase in the number of tariffs (a decrease in trade openness) will result in an appreciation of the real exchange rate. According to Edward 1989, economic openness is an economic fundamental factor that affects the real exchange rate because it is a proxy of trade control policies that will cause depreciation of the exchange rate. Easing control of trade will increase the flow of goods and services from and to foreign countries, which will mainly increase imports and will subsequently cause the exchange rate to depreciate

Trade Openness $=\frac{\text { Export+Import }}{\text { PDB }}$

Source : Edward (1989)

\section{H5: There is a association between OPN and REER}

The research model used in this study is to use the reference Lebdaoui (2013) entitled "The Real Exchange Rate Misalignment: Application of Behavioral Equilibrium Exchange Rate BEER to Morocco". Although using referrals, the independent variables in this study are different from the researchers' reference research.

The Model Specification used is as follows:

REER = f (tot, tnt, nfa, rdif,opn)

To explain the amount of currency Misalignment during the period 2000q1-2018q3, the estimated equilibrium value is calculated using the BEER model contained in equation 12. Then Misalignment is calculated by looking at the difference between REER and BEER, as in equation 13.

LREER $=\beta 0+\beta 1$ Ltot $+\beta 2$ Ltnt $+\beta 3$ Lnfa $+\beta 4$ Lrdif $+\beta 5$ Lopn $+\varepsilon_{i}$

Misalignment $=$ REER - BEER

\section{RESULT AND DISCUSSION}

Unit Root Test 
This study measures one dependent variable and five independent variables. To avoid the instability of the data, an analysis is made so that the data from the unit root test (unit root test). Gujarati (1995) see the unit root root test can be done with two methods, Augmented Dickey Fuller Test and Phillips Perron Test.

From the results of the ADF Test and Phillips Perron Test on the level series it is known that all statistical values are smaller than Mac Kinnon Critical Value. This means that the variable has unit root except for the variable real interest rate differential. The next step is to do the first differentiation of the data. The ADF and PP test results on the first difference indicate that the data is stationary at first difference

\section{Cointegration Rank Test}

Based on the comparison of Trace Statistic and Critical Value with Alpha 5\% (0.05) in this cointegration test, it can be stated that there is cointegration or long-term correlation between variables in this study. The existence of cointegration in this study is stated by the results of the Trace Statistic comparison (116.7478) greater than the Critical Value Alpha 5\%.

Table 1: Unrestricted Cointegration Rank Test (Trace)

Unrestricted Cointegration Rank Test (Trace)

\begin{tabular}{ccccc}
\hline \hline $\begin{array}{c}\text { Hypothesized } \\
\text { No. of CE(s) }\end{array}$ & Eigenvalue & $\begin{array}{c}\text { Trace } \\
\text { Statistic }\end{array}$ & $\begin{array}{c}\mathbf{0 . 0 5} \\
\text { Critical Value }\end{array}$ & Prob.** \\
\hline \hline None * & 0.535945 & $\mathbf{1 1 6 . 7 4 7 8}$ & $\mathbf{9 5 . 7 5 3 6 6}$ & 0.0009 \\
At most 1 & 0.335447 & 60.70194 & 69.81889 & 0.2144 \\
At most 2 & 0.216536 & 30.87121 & 47.85613 & 0.6734 \\
At most 3 & 0.092936 & 13.05697 & 29.79707 & 0.8890 \\
At most 4 & 0.057232 & 5.936412 & 15.49471 & 0.7031 \\
At most 5 & 0.022137 & 1.634147 & 3.841466 & 0.2011 \\
\hline \hline
\end{tabular}

Source: Extract from Eviews 9.0 output 
International Journal of Social Science and Economic Research

ISSN: 2455-8834

Volume: 05, Issue: 05 "May 2020"

\section{Error Correction Model}

Table 2: Long Run Error Correction Model

\begin{tabular}{|l|l|l|l|l|}
\hline \multicolumn{1}{|c|}{ Variable } & \multicolumn{1}{|c|}{ Coefficient } & \multicolumn{1}{|c|}{ Std. Error } & \multicolumn{1}{c|}{ t-Statistic } & \multicolumn{1}{c|}{ Prob. } \\
\hline \hline TOT & -28.97177 & 5.207564 & -5.563402 & 0.0000 \\
NFA & -67.43402 & 16.51168 & -4.084020 & 0.0001 \\
TNT & -7.931240 & 4.322276 & -1.834969 & 0.0708 \\
OPENNES & -0.067597 & 0.076679 & -0.881552 & 0.3811 \\
RDIF & -0.189146 & 0.261325 & -0.723796 & 0.4716 \\
C & 158.1215 & 14.01027 & 11.28611 & 0.0000 \\
\hline \hline R-squared & 0.653986 & Mean dependent var & 87.63058 \\
Adjusted R-squared & 0.628912 & S.D. dependent var & 9.403154 \\
S.E. of regression & 5.728117 & Akaike info criterion & 6.405269 \\
Sum squared resid & 2263.981 & Schwarz criterion & 6.590668 \\
Log likelihood & -234.1976 & Hannan-Quinn criter. & 6.479297 \\
F-statistic & 26.08274 & Durbin-Watson stat & 0.376554 \\
Prob(F-statistic) & 0.000000 & \multicolumn{2}{|l}{} \\
\hline
\end{tabular}

Source: Extract from Eviews 9.0 output

Based on table 2, the net foreign asset (nfa) variable influences the real exchange rate with a coefficient of - 67.43402 indicating that for every increase in net foreign asset growth of one percent in the previous period it will result in a real exchange rate appreciation of 67.43402 percent in the current period. This coefficient with a 95\% confidence level significantly influences the real exchange rate. This is because net foreign assets reflect the availability of Indonesia's foreign exchange reserves which will reduce the impulse of speculation. The bigger the nfa we have will increase investor confidence that Indonesia is strong enough to face external disturbances (external shock), causing an appreciation of the value of the rupiah exchange rate against the dollar.

The openness variable as a measure of trade control policy affects the exchange rate with a coefficient of 0.067597 indicating that for every increase in trade market share growth against GDP, which means a one percent reduction in trade control in the previous period will result in a real appreciation of 0.067597

The results of the terms of trade variable show a negative result. The substitution effect that is more dominant than income is a factor that shows a negative correlation. The substitution effect tends to be imported goods, making the real effective exchange rate depreciate more. 
International Journal of Social Science and Economic Research

ISSN: $2455-8834$

Volume: 05, Issue: 05 "May 2020"

These coefficients catch the effect of each fundament's behaviour in the exchange model, according to our estimated results of the cointegrating vectors $\beta$ the long-run equilibrium equation can be written as:

\section{REER $=158.1215-28.97177$ TOT - 67.43402NFA - 7.931240TNT $-0.0675970 P E N N E S$ - 0.189146RDIF}

Table 3: Short Run Error Correction Model

\begin{tabular}{|l|c|c|c|c|}
\hline \multicolumn{1}{|c|}{ Variable } & Coefficient & Std. Error & t-Statistic & Prob. \\
\hline D(TOT) & -18.94483 & 4.611799 & -4.107905 & 0.0001 \\
\hline D(NFA) & -22.97297 & 16.38731 & -1.401876 & 0.1656 \\
\hline D(TNT) & -22.38333 & 6.977794 & -3.207795 & 0.0021 \\
\hline D(OPENNES) & -0.03723 & 0.058312 & -0.638469 & 0.5253 \\
\hline D(RDIF) & -0.105032 & 0.17716 & -0.592865 & 0.5553 \\
\hline RES(-1) & -0.162594 & 0.065648 & -2.476754 & 0.0158 \\
\hline C & 0.285149 & 0.354599 & 0.804145 & 0.4242 \\
\hline R-squared & 0.295007 & Mean dependent var & 0.16901 \\
\hline $\begin{array}{l}\text { Adjusted } \\
\text { Rsquared }\end{array}$ & 0.231873 & S.D. dependent var & 3.37218 \\
\hline $\begin{array}{l}\text { S.E. of } \\
\text { regression }\end{array}$ & 2.955476 & Akaike info criterion & 5.09501 \\
\hline $\begin{array}{l}\text { Sum squared } \\
\text { resid }\end{array}$ & 585.2341 & \multicolumn{2}{|c|}{ Schwarz criterion } & 5.31297 \\
\hline Log likelihood & -181.5155 & Hannan-Quinn criter. & 5.18196 \\
\hline F-statistic & 4.672729 & Durbin-Watson stat & 1.76974 \\
\hline Prob (F statistic) & 0.000502 & \multicolumn{3}{|l}{} \\
\hline
\end{tabular}

Source: Output from eviews 9.0

For short run equilibrium equation can be written as:

\section{D $($ REER $)=158.1215-18.94483 D(T O T) \quad-22.97297 D(N F A) \quad-22.38333 D(T N T) \quad-$ 0.037230D(OPENNES) - 0.105032D(RDIF) - 0.162594RES(-1)}

Based on the results of the short-term test from table 3, it was found that the net foreign asset (nfa) variable affected the real exchange rate with a coefficient of -22.97297 indicating that for every increase in net foreign asset growth of one percent in the previous period, the real exchange rate appreciation was $22.97297 \%$. This coefficient with a 95\% confidence level significantly influences the real exchange rate. This is because net foreign assets reflect the 
availability of Indonesia's foreign exchange reserves which will reduce the impulse of speculation. The bigger the nfa we have will increase investor confidence that Indonesia is strong enough to face external disturbances (external shock), causing an appreciation of the value of the rupiah exchange rate against the dollar. Improving foreign assets will make foreign exchange reserves also improve. If foreign exchange reserves improve, there will be excessive dollar demand and the position of foreign exchange reserves will not be disturbed excessively and the exchange rate position will also be relatively stable. This model has $R^{2}$ of 0.295007 and able to describe the reer correlation with the five variables.

\section{Misalignment}

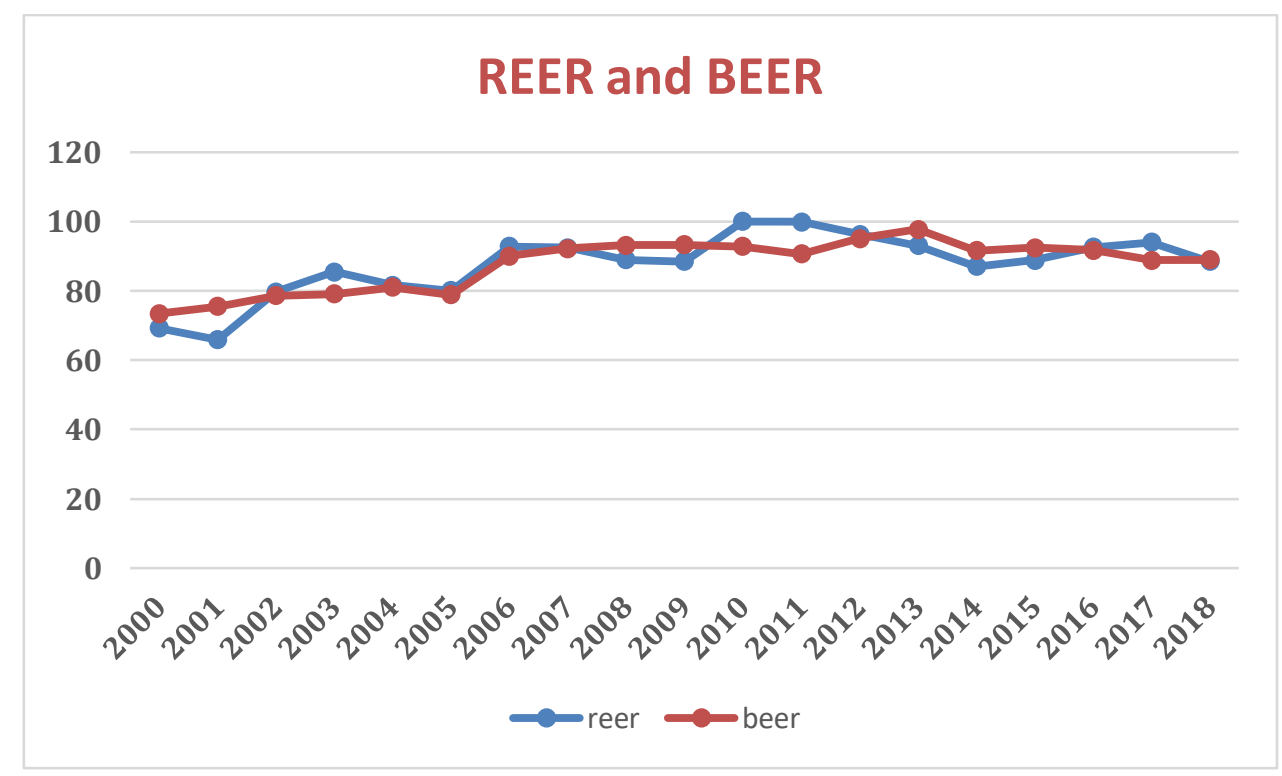

Figure 1: REER dan Estimation of BEER 


\section{International Journal of Social Science and Economic Research}

ISSN: $2455-8834$

Volume: 05, Issue: 05 "May 2020"

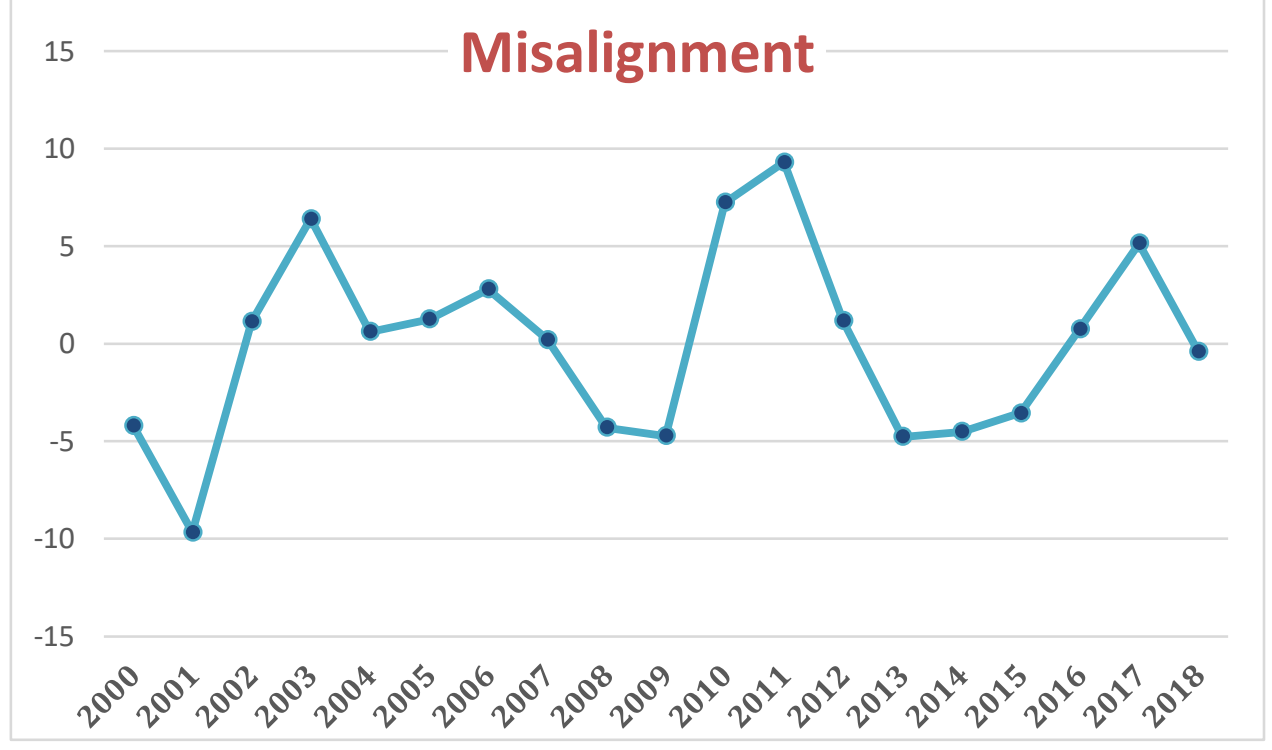

Figure 2: Misalignment

To facilitate analysis, the study period is divided into 8 sub-periods, which will show different patterns of misalignment :

1. Period I (2000Q1-2002Q1) : Undervalued misalignment

According to the Indonesian Economic Report, the rupiah exchange rate has tended to weaken and fluctuate since May 2000 in line with the warming of domestic political and security conditions, in addition to the pressure arising from the gap in demand and supply in the foreign exchange market. Meanwhile, the pressure on inflation continued to increase due to the relatively slow supply side to offset the increase in demand side due to various structural economic problems that still existed. On the one hand, rising inflationary pressures and the rupiah exchange rate demanded Bank Indonesia to tighten in the monetary sector. From the external side, the tendency to slow down the expansion of the United States economy in 2001 is expected to push down US dollar interest rates, which in turn will hinder the pace of appreciation of the US dollar globally. The development of the rupiah exchange rate during 2001 still experienced high depreciation pressure accompanied by increased volatility even though it had strengthened in the middle of the year. In general, the weakening of the exchange rate was caused by the existence of macro-fundamental and micro-structural problems in the foreign exchange market which led to an imbalance in supply and demand for foreign exchange.

The misalgnation calculation for the period was $-2.94 \%$ to $-13,514 \%$ in 2001 in the second quarter. From the macro-fundamental aspects, the increase in risk and uncertainty during 2001 has reduced the confidence of foreign investors in investing their funds 


\section{International Journal of Social Science and Economic Research}

ISSN: $2455-8834$

Volume: 05, Issue: 05 "May 2020"

domestically, hampering capital inflows. On the other hand, the deteriorating performance of the world economy in general has a negative impact on Indonesia's export performance. The two factors above have caused limited supply of foreign exchange at home, while at the same time there has been an increase in foreign exchange demand, especially by the corporate sector for repayment of foreign debt and import needs. The weakening of the rupiah exchange rate also put pressure on the high inflation in 2001.

2. Period II (2002Q2-2004Q1) : Overvalued

Even though the rupiah exchange rate had fallen to the lowest value of Rp. 9,425 per US dollar due to the "shock" tragedy of Bali in October 2002, the rupiah returned gradually to strengthen after the Bali tragedy. With these developments, the rupiah was recorded as the "second best performing currency" in the Asia Pacific after the New Zealand dollar. The tendency of the strengthening of the rupiah, especially after the Bali tragedy, was inseparable from a variety of positive sentiments, the rupiah exchange rate stabilization efforts carried out by Bank Indonesia, which proved effective in dampening the volatility of the rupiah exchange rate and holding back the rupiah did not weaken, especially soon after the tragedy Bali. The range of misalignment for the period was $2.225 \%-7.030 \%$, the highest in the fourth quarter of 2003.

3. Period III (2004Q2-2005Q3) : Overvalued

The rupiah exchange rate in general depreciated in 2005. This condition was mainly related to the weakening of the balance of payments performance due to the adverse conditions of the external and internal sectors, thus providing fundamental pressure on the rupiah exchange rate. On the external side, soaring world oil prices and the continued tight monetary policy in the US have provided depreciating pressure on the rupiah. Internally, the increase in demand for foreign currency, especially to meet the needs of imports and repayment of foreign debt, was the main factors triggering pressure on the rupiah. In the midst of domestic financial market conditions that still experience excess rupiah liquidity, foreign exchange demand is accelerating in line with increased expectations of depreciation due to soaring inflation. These various factors put strong pressure on the rupiah exchange rate. The value of misalgnation in this period is quite balanced, namely around the range of $-2.73 \%$ to $0.775 \%$

4. Period (2005Q4-2006Q1) : Highest Overvalued

The rupiah value was again appreciated in the fourth quarter of 2005 in line with the policies adopted by Bank Indonesia and the Government. The policy coordination had a positive impact and succeeded in restoring market confidence, as reflected in the reduced 


\section{International Journal of Social Science and Economic Research}

ISSN: $2455-8834$

Volume: 05, Issue: 05 "May 2020"

expectations of depreciation and increased inflows of foreign capital into the domestic financial market. During quarter IV-2006 the rupiah exchange rate moved more stable with a tendency to strengthen. The more stable movement of the rupiah was reflected in volatility which declined to $0.46 \%$ from $0.85 \%$ in the previous quarter. The stability of the rupiah was supported by improved economic fundamentals in the fourth quarter of 2006. Some economic indicators - such as export performance, GDP growth and inflation rate - show improvement. In line with global demand and rising export commodity prices, export performance continued to increase where in the period January - October 2006 non-oil and gas exports grew to reach $19.4 \%$. In the same period, non-oil and gas imports only grew $0.5 \%$ resulting in a relatively high current account surplus. Export commodity prices which continue to increase higher than import prices also increase Indonesia's terms of trade. In this period the rupiah experienced overvalued $7.76 \%$ in the fourth quarter of 2005 and $13.04 \%$ in the first quarter of 2006.

5. Period V (2006Q2-2009Q3) : Undervalued

The maintained stability of the rupiah was supported by improving domestic macroeconomic conditions and reduced external pressure. The stability of the rupiah was supported by improved economic fundamentals in the fourth quarter of 2006 . Then in 2007 the third quarter to 2009 in the second quarter, the rupiah experienced undervalued. The value of the misalignment range in this period was $-10.161 \%$ in the first quarter of 2009 and $-1.24 \%$ in the third quarter of 2008 .

6. Period VI (2009Q4-2012Q2) : Overvalued

Equilibrium exchange rates are relatively stable, but REER tends to be overvalued with a range of misalgnations of $0.68 \%$ to $11.63 \%$ in the second quarter of 2011 . In the 2012 Bank Indonesia Economic Report, it was stated that in maintaining the stability of the rupiah exchange rate, Bank Indonesia always conducted intensive monitoring and communication with market participants. In addition, to maintain balance in the domestic foreign exchange market, Bank Indonesia also intervened in the form of spot and forward transactions. The existence of Bank Indonesia in the domestic foreign exchange market was able to provide confidence to market participants so that the movement of the rupiah exchange rate was relatively stable. This condition was achieved amid the negative sentiment pressure due to global economic conditions and the government's plan to adjust policies related to subsidized fuel.

7. Period VII (2012Q3-2016Q2) : Undervalued

The tendency is undervalued. In mid-2013, the rupiah experienced relatively strong depreciation pressures, both fundamentally (BEER) and REER. A number of analyzes of 


\section{International Journal of Social Science and Economic Research}

ISSN: $2455-8834$

Volume: 05, Issue: 05 "May 2020"

msialignment focused on the effect of tantrum taper namely the reduction of quantitative easing stimulus announced in 2013 II as a key driving factor the misalgnment. The misalgnment value for the period was $-8.28 \%$ to $-0.4024 \%$.

8. Period VIII (2016Q3-2018Q3) : Undervalued

In this periode, rupiah was overvalued but declined in 2018Q1. The rupiah exchange rate depreciation triggered by the strengthening of the US dollar was relatively limited compared to other peers. Likewise, the volatility of the Rupiah despite an increase, is still at a lower level compared to peer countries. In the first quarter of 2018, the rupiah exchange rate experienced a depreciation triggered by a broad-based US dollar strengthening. In the first quarter of 2018, the daily average rupiah weakened $0.29 \%$ to Rp13,576 per US dollar. Point to point, the rupiah weakened by $1.47 \%$ in the first quarter of 2018 to Rp13,765 per US dollar. The rupiah exchange rate depreciated again in April 2018. On average, the Rupiah weakened $0.36 \%$ to Rp13,809 per US dollar in April 2018. Point-to-point, the rupiah weakened $1.06 \%$ to Rp13,913 per US dollar. In addition, the Rupiah exchange rate depreciation was caused by liquidity adjustments made by global investors who began to reduce fund placements in emerging market countries, including Indonesia. The depreciation of the Rupiah exchange rate is relatively limited compared to the movements of foreign exchange rates of other peers. Depreciation of the rupiah exchange rate in April 2018 is lower than other peers, including Turkish Lira 1.36\%, Indian Rupees 2.23\%, South African Rand 4.75\%, and Brazilian Real 5.70\%.. Pressure on outflow of funds increased in April 2018 in line with the increase in US yields that occurred. Based on the type of instrument, the outflow of funds occurred in all types of domestic assets, especially in short-term sovereign debt,shares, and government securities.

The range of misalgnment values in this period is $-2.23 \%$ to $5.96 \%$. Although the nominal rupiah value experienced a significant increase in the first and second quarters of 2018, the results of misalgnation calculations in this period included overvalued $1.4 \%$ in the first quarter of 2018, and undervalued $0.5 \%$ in the second quarter, and in the third quarter undervalued by $2.23 \%$. Undervalued values that are not too large can indicate that intervention efforts by Bank Indonesia can minimize the occurrence of exchange rate misalignations.

\section{CONCLUSION AND RECOMMENDATIONS}

This research conducted in analyzing the effect of the variables net foreign assets, terms of trade, relative price of non-traded to traded goods and real interest rate differential. Based on the results of the research and analysis carried out by the researcher, the following conclusions are 
International Journal of Social Science and Economic Research

ISSN: $2455-8834$

Volume: 05, Issue: 05 "May 2020"

obtained. It is found that a significant determinant of long-run equilibrium exchange rates is net foreign assets and the short term terms of trade are terms of traded and relative price of nontraded to traded goods. Based on the estimation of currency misalignment, it is concluded that the rupiah tends to approach equilibrium exchange rates during the study period. The findings of this study indicate that the rupiah is still vulnerable to undervaluation shocks. Misalignment range in the period $2000 \mathrm{q} 1-2018 \mathrm{q} 3$ is $-13,514 \%$ up to $13.04 \%$ with an undervalued tendency.

For subsequent research that will be more in researching misalignment can add variables and review the variables that will be included in the study so that the results obtained are significant. For the Government, especially the central bank, it can be an input in monetary policy. Particularly for the transparant of rupiah intervention in the foreign exchange market. Investors and prospective investors who have rupiahs can be a signal for companies or individuals to be able to consider the decision to sell or buy foreign exchange in dollars or rupiah.

\section{ACKNOWLEDGEMENT}

We thank Research Cluster of Governance and Competitiveness, Faculty of Administrative Science, Universitas Indonesia for providing supporting materials in regards to discussions and assisting us in writing this journal.

\section{REFERENCES}

Abimanyu, Yoopi, (2004). Memahami Kurs Valuta Asing. Jakarta: Fakultas Ekonomi Universitas Indonesia.

Baffes, J., I. Elbadawi, and S. O'Connell (1999). Single Equation of the Equi- librium Real Exchange Rate. In L. Hinkle and P. Montiel (eds.), Exchange Rate Misalignments: Concepts and Measurement for Developing Countries. A World Bank Research Publication. New York: Oxford University

Bank Indonesia (2000-2017). Laporan Perekonomian Indonesia.Jakarta, Indonesia.

Bank Indonesia SDSS : Neraca Pembayaran Indonesia dan Posisi Investasi Internasional.Jakarta, Indonesia

Caballero, Ricardo J. \& Corbo, Vittorio, 1989. "How does uncertainty about the real exchange rate affect exports?," Policy Research Working Paper Series 221, The World Bank.

Clark, Peter \& MacDonald, Ronald. (2004). Filtering the BEER - A Permanent and Transitory Decomposition. Global Finance Journal. 15. 29-56. 10.1016/j.gfj.2003.10.005. 
International Journal of Social Science and Economic Research

ISSN: 2455-8834

Volume: 05, Issue: 05 "May 2020"

Dornbusch, Rudiger, (1974), "Tariffs and Nontraded Goods", Journal of International Economics, Vol.7 (May), pp. 177-85

Edwards, S., 1988, Exchange Rate Misalignment in Developing Countries (Baltimore, MD: The Johns Hopkins University Press).

Elbadawi, Ibrahim A. \& Soto, Raimundo, 1994. "Capital flows and long-term equilibrium real exchange rates in Chile," Policy Research Working Paper Series 1306, The World Bank.

Faruqee, H.(1995),"Long-run determinants of thereal exchange rate: A stock- flow perspective", IMF Staff Papers 42 (1), 80-107.

Gujarati, Damodar. 1995. Ekonometrika Dasar. Alih Bahasa Sumarno Zain. Erlangga : Jakarta.

Husman, Jardine Ariena, (2005), Pengaruh Nilai Tukar Riil Terhadap Neraca Perdagangan Bilateral Indonesia, Bulletin of Monetary Economics and Banking, 8, issue 3, p. 1-26.

Klau, Marc, and San Sau Fung. 2006. The New BIS Effective Exchange Rate Indices.”BIS Quarterly Review, March

Kurniati, Yati dan A.V. Hardiyanto, 1999, "Perilaku Nilai Tukar Rupiah dan Alternatif Perhitungan Nilai Tukar Riil Keseimbangan", Bank Indonesia Buletin Ekonomi Moneter dan Perbankan, Vol. 2, No. 2, September.

Lebdaoui, Hind. (2013) The Real Exchange Rate Misalignment: Application of Behavioral Equilibrium Exchange Rate BEER to Morocco1980Q1-2012Q4. International Journal of Economics and Finance; Canadian Center of Science and Education Vol. 5, No. 10

MacDonald, Ronald, 1997, "What Determines Real Exchange Rates? The Long and Short of It", IMF Working Paper/97/21, (Washington: International Monetary Fund).

Montiel, P. (1999). Determinants of the Long-Run Equilibrium Real Exchange Rate: An Analytical Model. In P. J. Montiel and L. E. Hinckle (eds.), Exchange Rate Misalignments: Concepts and Measurement for Developing Countries. A World Bank Research Publication. New York: Oxford Univer- sity Press.

Ronald MacDonald \& Peter B. Clark, 1998. "Exchange Rates and Economic Fundamentals; A Methodological Comparison of BEERs and FEERs," IMF Working Papers 98/67, International Monetary Fund. 
International Journal of Social Science and Economic Research

ISSN: $2455-8834$

Volume: 05, Issue: 05 "May 2020"

Ronald MacDonald and Preethike Dias, 2007. "Behavioural equilibrium exchange rate estimates and implied exchange rate adjustments for ten countries," Working Papers 2007_12, Business School - Economics, University of Glasgow.

Sahminan, 2005. "Estimating Equilibrium Real Exchange Rates of the Rupiah," Working Papers WP/8/2005, Bank Indonesia. 